\title{
Indeterminate Microsatellite Instability
}

National Cancer Institute

\section{Source}

National Cancer Institute. Indeterminate Microsatellite Instability. NCI Thesaurus. Code C158894.

An indication that microsatellite instability was not assessed or that it is not known if it was assessed. 